O板垣政信 ${ }^{11}$ 小林俊光 ${ }^{21}$ 橋本 省 ${ }^{11}$ 欠㚼誠治 ${ }^{21}$ 池田勝久 ${ }^{21}$ 高坂知節 ${ }^{21}$

1) 国立仙台病院耳鼻科 2) 東北大学耳鼻科

I はじめに

聴神経腫瘍の $5 \sim 20 \%$ 突発難聴を初発症状とするものがあることは良く知られてい る。しかし、聴神経腫瘍を診断する一般耳鼻科医の立場からすると、突発性難聴の診断基 準を満たした症例の中にどの程度の率で聴神経腫瘍が存在するかを知っておくこともまた 大きな意義があるように思われる。

今回、われわれは当科を受診し、突発性難聴の診断基準を満たす全症例にMRIを行い 聴神経腫瘍を初めとする頭蓋内病変の陽性率を検討したので結果を報告するとともに、突 発性難聴におけるMＲＩの有用性につき考察する。

\title{
II 対象および方法
}

1991 年 4 月より1993 年 7 月までに東北大学耳鼻咽喉科外来を受診し、突発性難 聴と診断された症例にルーチンに脳M R I を施行した。M R I 施行上の制約などにより撮 影できなかった症例を除き 56 例( 男 28 例、女 28 例；年齢 13 才〜 78 才、 平均 50 . 0 才) の M R I を検討の対象とした。M R I は $3 \mathrm{~mm}$ スイスにて撮影し、 $\mathrm{T}_{1}, \mathrm{G} \mathrm{d}-\mathrm{T}_{1}, \mathrm{~T}_{2}$ 水平断と $\mathrm{G} \mathrm{d}-\mathrm{T}_{1}$ 冠状断を基本とした。

\section{III 結果}

(1) M R I にて「所見あり」と判定されたものが 11 例、「所見なし」と判定されたもの が 45 例であった。

(2)「所見あり」1 1 例の内訳は表 1 の如くである。

(3)聴神経腫瘍は 1 例 $(1.8 \%)$ であった。この症例の発症状況は、ほかの突発性難聴 症例とまったく違いがなく突然の難聴であった。発症後 11 日目に受診し、図 1 の如 $<1000 \mathrm{~Hz} \cdot 2000 \mathrm{~Hz}$ 中心の $77.5 \mathrm{~d} \mathrm{~B}$ の難聴がみられ、60 m gからのステロイド内 服治療が行われたが難聴の回復はみられなかった。M R I は発症 31 日後に撮影され た。内耳道から後頭蓋窝へわずかに乫出する小腫瘍が認められ手術にて確認された。

\section{IV 考察}

M R I の普及により、聴神経腫瘍の診断は確実なものとなったが、突発性難聴の診断基 準を満たした症例の中にどの程度の率で聴神経腫瘍が存在するかについての検討は過去に は行われていないようである。

われわれは、今回 2 年 3 か月間に当科で治療した突発性難聴全例にMRIをルーチンに 施行し、M R I による聴神経腫瘍を初めとする頭蓋内病変の陽性率を検討した。その結果 
聴神経腫瘍は 1 例（1．8％) であった。この率はM R I によらない Shaia (1975)の 1220 例中 10 例 (0.8\%) よりやや大きい数字となっている。

その他 10 例に何らかの頭蓋内病変が観察された。この中で椎骨動脈走行異常 1 例、高 位䅡静脈球症 2 例は難聴との関係が推定されたが、その他は難聴との直接の関係は否定的 であった。しかし、これらには循環障害を示唆する所見が多く含まれ、これらの患者にお ける突発性難聴の素因を示すものとも考えられる。

V まとめ

当科を受診した突発性難聴に対してルーチンにMR I を施行した。その結果 56 例中 1 例の聴神経腫瘍、10 例のその他の頭蓋内病変の存在が明らかとなった。

表 1

所見あり 11 例の内訳

1 ) 直接関係のあるもの・・・・聴神経腫瘍 1 例

2) 関係の疑われるもの・・・椎骨動脈走行異常 1 例 高位静脈球症 1 例

3) 関係が否定できないもの・・脳虚血性変化 5 例

$\begin{array}{ll}\text { 哚部白質 } & 3 \text { 例 } \\ \text { 脳幹部 } & 1 \text { 例 }\end{array}$

深部白質および脳幹部 1 例

4 ) 関係がほとんどないもの・・小脳 cavenous angioma 1 例 硬膜下血腫

1 例

図 1 聴神経腫瘍例の聴力像

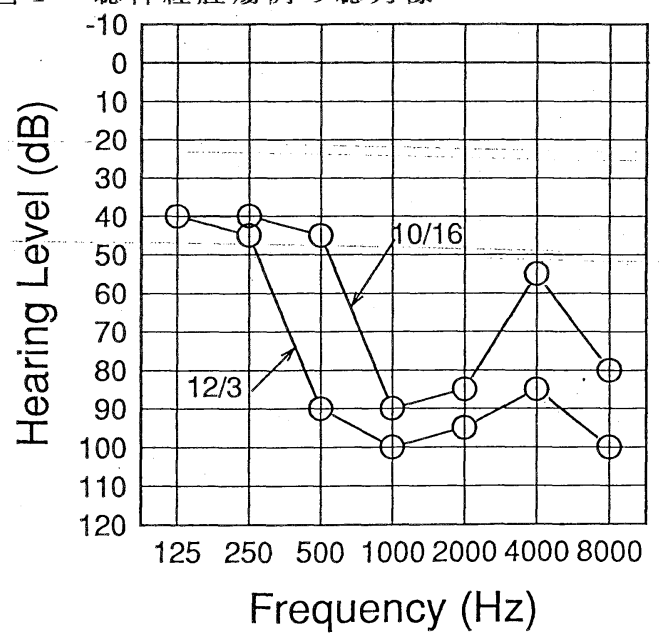

